University of Nebraska - Lincoln

DigitalCommons@University of Nebraska - Lincoln

Publications from USDA-ARS / UNL Faculty

U.S. Department of Agriculture: Agricultural

Research Service, Lincoln, Nebraska

2012

\title{
Attraction of Stomoxys sp. to various fruits and flowers in Mali
}

Günter Müller

Hebrew University, guntercmuller@hotmail.com

Jerome Hogsette

United States Department of Agriculture-ARS-Center for Medical, Jerry.Hogsette@ars.usda.gov

University of Miami Beier

University of Miami

University of Bamako

University of Bamako

M.B. Toure

University of Bamako

See next page for additional authors

Follow this and additional works at: https://digitalcommons.unl.edu/usdaarsfacpub

Part of the Agricultural Science Commons

Müller, Günter; Hogsette, Jerome; University of Miami Beier; University of Bamako; Toure, M.B.; Traore, M.M.; Bah, S.; Doumbia, S.; and Schlein, Y., "Attraction of Stomoxys sp. to various fruits and flowers in Mali" (2012). Publications from USDA-ARS / UNL Faculty. 1025.

https://digitalcommons.unl.edu/usdaarsfacpub/1025

This Article is brought to you for free and open access by the U.S. Department of Agriculture: Agricultural Research Service, Lincoln, Nebraska at DigitalCommons@University of Nebraska - Lincoln. It has been accepted for inclusion in Publications from USDA-ARS / UNL Faculty by an authorized administrator of DigitalCommons@University of Nebraska - Lincoln. 


\section{Authors}

Günter Müller, Jerome Hogsette, University of Miami Beier, University of Bamako, M.B. Toure, M.M. Traore, S. Bah, S. Doumbia, and Y. Schlein 


\title{
Attraction of Stomoxys sp. to various fruits and flowers in Mali
}

\author{
G. C. M ÜLLER ${ }^{1}$, J. A. HOG SET T E ${ }^{2}$, J. C. B E I E R ${ }^{3}$, S. F. T R A O R E \\ M. B. T OURE ${ }^{4}$, M. M. TR A ORE $E^{4}$, S. B A H ${ }^{5}$, S. DOUMB I A ${ }^{4}$ and \\ Y. S C H L E I N
}

${ }^{1}$ Department of Parasitology, Hebrew University, Jerusalem, Israel, ${ }^{2}$ United States Department of Agriculture-ARS-Center for Medical, Agricultural, and Veterinary Entomology, Gainesville, FL, U.S.A., ${ }^{3}$ Department of Epidemiology and Public Health, University of Miami, Miami, FL, U.S.A. and Abess Center for Ecosystem Science and Policy, University of Miami, Coral Gables, FL, U.S.A., ${ }^{4}$ Faculty of Medicine, Pharmacy and Odontostomatology, University of Bamako, Bamako, Mali and ${ }^{5}$ Department of Pharmaceutical Sciences, University of Bamako, Bamako, Mali

\begin{abstract}
The attraction of three Stomoxys species to 26 fruits and 26 flowers of different plant species was investigated in two different sites in Mali during 2008. Stomoxys niger bilineatus Grunberg (Diptera: Muscidae) was attracted to a wider spectrum of species, significantly attracted by four fruits and eight flowers compared with control traps, whereas $S$. sitiens Rondani (Diptera: Muscidae) was attracted to six fruits and seven flowers of different plants, and S. calcitrans L. (Diptera: Muscidae) was only attracted to one fruit and three flowers. Cold anthrone assays showed a significantly higher prevalence of sugar feeding amongst all three species at the lagoon site than at the site near Mopti. The rhythm of activity study shows temporally separated blood- and sugar-feeding periods for $S$. niger bilineatus and $S$. sitiens, but not for S. calcitrans. A comparison between blood and sugar feeding throughout the day shows that sugar feeding activity is as frequent as blood feeding activity. Because not much is known about the preferred sugar sources for Stomoxys species in their natural habitats, the present study provides valuable information regarding the attraction capability of several plants with possible future implication for Stomoxys control strategies.
\end{abstract}

Key words. Stomoxys calcitrans, S. niger bilineatus, Stomoxys sitiens, glue traps, nectar feeding, stable flies.

\section{Introduction}

Biting stable flies of the genus Stomoxys are considered major pests of pasture cattle and livestock (Hogsette \& Farkas, 2000; Hogsette et al., 2008). Both male and female adults require three to five bloodmeals for successful mating, inflicting painful bites and subsequent bleeding which can result in lower average weight and decreased milk production, with enormous economical losses worldwide (Bruce \& Decker, 1958; Campbell et al., 1987, 2001). In the US alone losses to the cattle industry are estimated at over 1 billion \$US annually (Taylor \& Berkebile, 2006). Furthermore, Stomoxys is known to obtain bloodmeals from human sources when cattle or other animal hosts are lacking, and can be a major nuisance having major adverse effects on the tourism industry in areas prone to Stomoxys infestations (Hogsette et al., 1987). Zumpt (1973) lists the 18 known species of Stomoxys, with 14 of these found on the African continent (Mihok et al., 1995a). Stomoxys has been shown to transmit several

Correspondence: Jerome A. Hogsette, USDA-ARS-CMAVE, 1600 S.W. 23rd Drive, Gainesville, FL 32608, U.S.A. Tel.: +352-374-5702; Fax: +352-374-5922; E-mail: jerry.hogsette@ars.usda.gov 
parasitic organisms mechanically, such as Anaplasma marginale (Theiler) (Potgieter et al., 1981; Scoles et al., 2005), Trypanosoma evansi (D’Amico et al., 1996; Sumba et al., 1998), T. brucei and T. vivax (Mihok et al., 1995b), T. congolense (Sumba et al., 1998), capripox virus and African swine fever virus (Mellor et al., 1987). However, the few field transmission studies have shown Stomoxys to have a limited potential as vectors.

Although bloodmeals are the main protein source of the stable flies, and are a mandatory prerequisite for successful mating and ovarian development, observations of stable flies on flowering plants in the field (Eavy et al., 1981; Tseng et al., 1983) have suggested Stomoxys species may be imbibing nectar to supplement their bloodmeal diet. Indeed, a significant portion of Stomoxys flies have been shown to feed on plant-derived sugars (Mihok \& Clausen, 1996; Taylor \& Berkebile, 2008), especially when hosts which provide bloodmeals are scarce (Jones et al., 1985). Stomoxys flies are known to consume sugars within a few hours of eclosion, and were shown to continue feeding on sugars even when blood was supplied ad libitum (Jones et al., 1985). Sucrose solutions as well as flower cuttings and pollen extracts of selected wild plants have prolonged Stomoxys survival compared with water controls (Tseng et al., 1983; Jones et al., 1985), although not as much as bloodmeals (Moobola \& Cupp, 1978). Anthrone assays of wild Stomoxys populations in rural and urban locations in Nebraska revealed a larger per cent of sugar-fed stable flies compared with bloodfed, with a small correlation between nectar and blood feeding. This suggests that sugar feeding may increase the chance for successful blood-feeding by the stable flies (Taylor \& Berkebile, 2008).

Sugar feeding seems to be an important energy source for the stable fly (Hogsette et al., 1987), yet little is known about the preferences and attraction signals which are sensed by Stomoxys sp. Tseng et al. (1983) found that Stomoxys are most attracted to golden rod (Solidago fistulosa) and salt bush (Baccharis halimifolia) flowers in FL, U.S.A. Stomoxys flies contaminated with willow (Salix sp.) pollen have also been reported (Tseng et al., 1983; Jarzen \& Hogsette, 2008). The attraction of selected volatile compounds was compared in an attempt to increase trap efficiencies, however, the attractants were mainly related to blood-seeking or mating behaviour, and not to sugar-seeking behaviour (Mihok et al., 1995a). To date, very few studies have investigated the relationship between Stomoxys sp. and various plant species which exist in its natural environment.

In a previous field experiment which examined the attraction of Anopheles gambiae s.s. Giles to various fruit and flowers in Mali, a considerable number of Stomoxys flies were trapped along with the mosquitoes. Interestingly, a distinct preference to several fruit and flower baits by three Stomoxys species, namely S. calcitrans L., S. niger bilineatus Grunberg and S. sitiens Rondani, was observed. In the present study, we report the attraction efficiency of selected fruit and flowers to, as well as the diurnal feeding behaviour of, the three aforementioned species.

\section{Materials and methods}

\section{Trap description}

The attractiveness of fruits, seed pods and flowers was determined using a specially designed sticky trap which was constructed as follows: 1.5-L plastic bottles were cut in half and the bottom halves buried in the ground so the rims of the bottles were slightly higher than the soil surface. The bottles were then filled with water. Soil around the bottles was moistened with water and packed down to stabilize the bottles.

Stiff $(0.2-\mathrm{cm}$ thick) plastic mesh, $70 \times 70 \mathrm{~cm}$, with $0.8-\mathrm{cm}$ square holes, was rolled into cylinders and secured with plastic tie wraps. The tops were closed with circular pieces of the same material, also secured with plastic tie wraps. Each mesh cylinder was placed above a buried bottle. Before the mesh cylinders were secured in place, one of the following was placed inside: $0.5 \mathrm{~kg}$ of ripe fruit pieces arranged on wooden stakes (40 cm long), or $0.5 \mathrm{~kg}$ of freshly cut flowers (50-70 cm long) placed in the bottle of water. The cylinders were then fixed to the ground with $20-\mathrm{cm}$-long wooden stakes and painted with an adhesive (Tanglefoot; Tel Aviv, Israel) to capture insects that were attracted to these baits.

\section{Site description}

The Internal Delta of the Niger River, the main delta and associated wetlands, comprise an area of about $30000 \mathrm{~km}^{2}$ at an altitude of 263-271 $\mathrm{m}$ a.s.l. The delta proper is located in the centre of Mali and is about $400 \mathrm{~km}$ long, oriented SW$\mathrm{NE}$, with a mean width of about $90 \mathrm{~km}$. There is a population density of $500 / \mathrm{km}^{2}$ in the Delta, compared with a population density of $9 / \mathrm{km}^{2}$ in the remainder of the country. Recently an agro-pastoral system became established in which resident farmers grow rice and millet and at the same time produce their own cattle. Every year for 7-8 months, the pastures of the delta are grazed by 1200000 cattle and 1500000 sheep and goats, including the livestock of the semi-nomadic populations living nearby. Direct precipitation over the delta varies by year and location, with annual totals ranging from 200 to $600 \mathrm{~mm}$. The rainy season usually extends from July through to mid-October in the south, and from mid-July to mid-September in the north.

Some experiments were conducted at a natural site near a seasonal lagoon $\left(15^{\circ} 0^{\prime} 0^{\prime \prime} \mathrm{N}, 4^{\circ} 10^{\prime} 0^{\prime \prime} \mathrm{W}\right)$ approximately $50 \mathrm{~km}$ north of Sevare. The lagoon was about $4 \mathrm{~km} \mathrm{long}$ and surrounded by wooded grassland dominated by Acacia species. The site was visited daily by several groups of semi-nomads with about 500-1000 cattle. Every day, villagers working in nearby rice fields grazed several dozen tethered donkeys near the lagoon. Experiments were also conducted at a site at the outskirts of Mopti $\left(14^{\circ} 30^{\prime} 0^{\prime \prime} \mathrm{N}, 4^{\circ} 12^{\prime} 0^{\prime \prime} \mathrm{W}\right)$ in the middle of rice fields, about $10 \mathrm{~km}$ southwest of Sevare. Every day, donkeys and goats were grazing along the roads and trails crossing the rice fields. 


\section{Stomoxys attraction to fruit}

In November 2008, 28 sticky traps were placed at 20-m intervals along the shore of the seasonal lagoon. In total, 26 different fruit species (Table 1) and two controls were used as baits. Controls consisted of one unbaited sticky trap and one sticky trap baited with a sponge soaked with white-refined sugar solution.

Treatments (fruits and controls) were randomly assigned to four blocks of seven sticky traps, and placed in their assigned sticky traps at night. After 24 hours, Stomoxys spp. were removed from the sticky traps, counted and stored in $70 \%$ ethanol for later identification to species in the laboratory. Treatments were then rotated to the next block, and the adhesive was reapplied to the cleaned sticky traps, which were placed over the treatments for another $24 \mathrm{~h}$. This was repeated for seven consecutive nights.

\section{Stomoxys attraction to flowers}

In late October 2008, 28 sticky traps were placed at 20-m intervals along a road between rice fields at the Mopti site. Flowers of 26 different plant species (Table 2), collected within a 20-km radius of the Mopti site, and two controls were used as baits. Controls consisted of one unbaited sticky trap and one sticky trap baited with a sponge soaked with white-refined sugar solution.

Treatments (flowers and controls) were randomly assigned to four blocks of seven sticky traps, and placed in their assigned sticky traps at night. After $24 \mathrm{~h}$, Stomoxys spp. were removed from the sticky traps, counted and stored in $70 \%$ ethanol for later identification to species in the laboratory. Treatments were then rotated to the next block, and the adhesive was reapplied to the cleaned sticky traps, which were placed over the treatments for another $24 \mathrm{~h}$. This was repeated for six consecutive nights.

\section{Stomoxys sugar feeding}

To assess the percentage of flies which fed on sugar before blood-feeding, cold anthrone assays as described by Van Handel (1967) were performed on three groups of 100 flies of each species, collected randomly with a sweep net in the vicinity of a donkey at the lagoon and at the Mopti sites. Flies which showed obvious signs of recent blood feeding were discarded, but the remainder were tested on site.

\section{Rhythm of activity}

Diurnal feeding behaviour of the three Stomoxys species was investigated at the seasonal lagoon described above during mid-November 2008. Flies were collected from two traps baited with flowering Acacia albida, and from two donkeys using sweep nets. Collections were performed during 30-min intervals from 05.30 until 21.00.00 hours for three consecutive days and replicated six times for each interval: two donkeys or two groups of plant-baited sticky traps (six traps per group, data pooled) $\times 3$ days $=6$ reps.

\section{Weather}

The weather in Mali during October and November is very constant, with average temperatures ranging from 30 and $20{ }^{\circ} \mathrm{C}$, and $<1$ rain day per month (http://www.weatherforecast map.com/mali/mopti/). Thus, changes in weather did not interfere with our tests and weather variables were not recorded.

\section{Statistical analysis}

Fruit and flower data were first normalized by conversion to $\log _{10}(n+1)$ then subjected to general linear models (GLM) (SAS Institute, 2003) using the following main effects model statements: Stable flies captured $=$ Treatment Block Day, where treatment was either fruits or flowers, block was a grouping of seven treatments and day was one of the consecutive trapping days of each study. Relative attraction ratios were calculated for the fruit and flower data by dividing the mean number of flies captured by each treatment by the mean number of flies captured by their respective control traps.

Cold anthrone assay data were normalized by conversion to $\log _{10}(n+1)$ then subjected to GLM (SAS Institute, 2003) using the following main effects model statements: Per cent sugar fed = Location Species Day, where location was either Mopti or the lagoon sites, species was one of the three Stomoxys species and day was one of the consecutive trapping days of each study,

Sugar- and blood-feeding activity data were normalized by conversion to $\log _{10}(n+1)$ then subjected to GLM (SAS Institute, 2003) using variations of the following main effects model statements: Flies Captured/Trapped = Bait Time Species Rep, where bait was either the flower or the donkey, time was the capture/trapping time, species was one of the three Stomoxys species and rep was one of the six replications performed during three consecutive days. In the model variations, individual class variables were substituted as grouping variables, e.g. when analysed by Bait, the model becomes Flies Captured/Trapped $=$ Time Species Day, and so on.

Means for all analyses above were separated with the Ryan-Einot-Gabriel-Welsch Multiple Range Test (REGWQ), and unless otherwise stated, $P<0.05$ (SAS Institute, 2003). Although $\log _{10}(n+1)$ values were used for the analyses, actual values are reported in the text, figures and tables. Means reported in the text are in the form $\bar{x} \pm$ S.E.

\section{Results}

There were no significant differences between the mean numbers of any Stomoxys species captured by the two control traps (empty and sugar water baited), so only the results for the empty control trap are shown. The attraction to fruits and flowers decreased rapidly through the various treatments, so 
Table 1. Fruits, seed pods or stems from the following 26 plants were evaluated for attraction to Stomoxys calcitrans, S. niger bilineatus and S. sitiens in Mali.

\begin{tabular}{|c|c|c|}
\hline Common name & Family & Plant species \\
\hline \multicolumn{3}{|c|}{ Purchased from the market in Sevare: } \\
\hline Date & Arecaceae & Phoenix dactylifera $\mathrm{L}$. \\
\hline Papaya & Caricaceae & Carica papaya $\mathrm{L}$. \\
\hline Honey melon & Cucurbitaceae & Cucumis melo $\mathrm{L}$. \\
\hline Dwarf banana & Musaceae & Musa acuminata Colla \\
\hline Guava & Myrtaceae & Psidium guajava $\mathrm{L}$. \\
\hline Sugar cane & Poaceae & Saccharum officinarum $\mathrm{L}$. \\
\hline \multicolumn{3}{|c|}{ From southern Mali or imported: } \\
\hline Pineapple & Bromeliaceae & Ananas comosus (L.) Merr. \\
\hline Water melon & Cucurbitaceae & Citrullus lanatus (Thunb.) Matsum. \& Nakai \\
\hline Plantain & Musaceae & Musa $\times$ paradisiaca $\mathrm{L}$. \\
\hline Apple & Rosaceae & Malus domestica Borkh. \\
\hline Orange & Rutaceae & Citrus sinensis (L.) Osbeck \\
\hline Bitter orange & Rutaceae & Citrus aurantium $\mathrm{L}$. \\
\hline \multicolumn{3}{|c|}{ Edible fruits and seed pods collected from wild plants and trees in the delta: } \\
\hline \multirow[t]{2}{*}{ Bush melon } & Cucurbitaceae & Citrullus colocynthis (L.) Schrad. \\
\hline & Ebenaceae & Diospyros mespiliformis Hochst. ex A. DC. \\
\hline \multirow[t]{3}{*}{ Tamarind } & Fabaceae & Tamarindus indica $\mathrm{L}$. \\
\hline & Fabaceae & Piliostigma reticulatum (DC.) Hochst. \\
\hline & Fabaceae & Acacia albida Delile \\
\hline African fig & Moraceae & Ficus thonningii Blume \\
\hline \multirow[t]{2}{*}{ Jujube } & Rhamnaceae & Ziziphus mauritiana Lam. \\
\hline & Tiliaceae & Grewia bicolor Juss. \\
\hline Soapberry tree & Zygophyllaceae & Balanites aegyptiacus (L.) Delile \\
\hline \multicolumn{3}{|c|}{ Seed pods used only for animal fodder: } \\
\hline & Fabaceae & Acacia sieberiana DC. \\
\hline & Fabaceae & Acacia nilotica (L.) Delile \\
\hline & Fabaceae & Acacia seyal Delile \\
\hline & Fabaceae & Acacia macrostachya Rchb. ex DC. \\
\hline \multicolumn{3}{|l|}{ Fruits of: } \\
\hline Kangaroo apple & Solanaceae & Solanum vescum F. Muell. \\
\hline
\end{tabular}

only the top eight fruits and nine flowers are shown in the tables. Significantly $(F=27.86$, d.f. $=36,1070, P<0.0001)$ more flies were captured on flowers $(2.6 \pm 0.04)$ than on fruit $(2.3 \pm 0.03)$, species ignored.

\section{Stomoxys attraction to fruit}

The main effects model was significant $(F=15.14$, d.f. $=$ 34, 566, $P<0.0001)$ for fly species and fruits, but not for blocks or days. Overall, significantly more S. niger bilineatus $(3.8 \pm 0.06)$ were attracted to the fruits than $S$. calcitrans $(1.8 \pm 0.05)$ and $S$. sitiens $(1.7 \pm 0.04)$. Differences in attraction between the latter two species were not significant. The following seven fruits attracted significantly more Stomoxys, species overlooked, than the unbaited control trap: Piliostigma reticulatum, Psidium guajava, Tamarindus indica, Ficus thonningii, Saccharum officinarum, Cucumis melo and Carica papaya. The overlapping significance levels have been omitted here because they are more meaningful when the fly species are examined individually. There were no significant differences in attraction between the remaining 19 fruits and the unbaited control trap.

The fruit of Piliostigma reticulatum was the most attractive to all three Stomoxys species and attracted significantly more individuals than did their respective control traps (Table 3). Piliostigma reticulatum attracted significantly more S. calcitrans than the other 25 fruits; however, significance levels were wide and overlapping for the other two Stomoxys species. The Stomoxys species captured in the largest numbers was S. niger bilineatus, but the Stomoxys species with the highest relative attraction ratios was $S$. sitiens. It is interesting to note that 7 of the 26 fruits evaluated were the most attractive to all 3 Stomoxys species, although not entirely in the same order (Table 3). All 26 fruits attracted numerically more $S$. sitiens than did the control trap. However for S. calcitrans and S. niger bilineatus, 11 fruits, e.g. Citrus aurantium, Musa paradisiacal, Solanum vescum, Acacia nilotica and Ananas comosus (Table 1), attracted numerically fewer individuals than did their respective control traps. There were no significant differences between blocks or days. The relative attraction to fruits by $S$. sitiens was much higher than it was for the other two Stomoxys species (Table 3).

\section{Stomoxys attraction to flowers}

The main effects model was significant $(F=32.29$, d.f. $=$ 34, 503, $P<0.0001$ ) for fly species and fruits, but not for blocks or days. Overall, significantly more S. sitiens 
Table 2. Flowers from the following 26 plants were evaluated for attraction to Stomoxys calcitrans, S. niger bilineatus and S. sitiens in Mali.

\begin{tabular}{ll}
\hline Family & Plant species \\
\hline Apocynaceae & Leptadenia pyrotechnica (Forssk.) Decne. \\
Asclepiadaceae & Calotropis procera (Ait.) Ait. f. \\
Capparaceae & Boscia angustifolia A. Rich. \\
Capparidaceae & Gynandropsis gynandra (L.) Briq. \\
Combretaceae & Guiera senegalensis J. F.Gmel. \\
Convolvulaceae & Hypomoea asarifolia (Desr.) Roem. \& Schult. \\
Euphorbiaceae & Ricinus communis L. \\
Fabaceae & Acacia albida (Delile) A.Chev.* \\
Fabaceae & Acacia macrostachya Reichenb. ex Benth.* \\
Fabaceae & Acacia nilotica (L.) Willd. ex Delile* \\
Fabaceae & Acacia senegal Willd. \\
Fabaceae & Crotalaria retusa L. \\
Fabaceae & Cassia tora L. \\
Fabaceae & Cassia occidentalis L. \\
Fabaceae & Cassia siamea Lam. \\
Fabaceae & Indigofera astragalina DC. \\
Fabaceae & Parkinsonia acculeata L. \\
Lamiaceae & Hyptis suaveolens (L.) Poit. \\
Malvaceae & Abutilon sp. \\
Malvaceae & Hybiscus sabdarrifa L. \\
Pedaliaceae & Rogeria adenophylla J. Gay ex Delile \\
Pedaliaceae & Sesamum indicum L. \\
Rhamnaceae & Ziziphus mauritiana Lam.* \\
Rubiaceae & Mitracarpus scaber Zucc. \\
Scrophulariaceae & Striga hermontheca (Del.) Benth. \\
Solanaceae & Physalis sp. (possibly angulata L.) \\
&
\end{tabular}

*Seed pods from these trees were also tested for Stomoxys attraction.

$(4.5 \pm 0.08)$ were attracted to the flowers than S. niger bilineatus $(2.1 \pm 0.07)$ and $S$. calcitrans $(1.8 \pm 0.06)$. Differences in attraction between the last two species were not significant. Flowers from the following nine plants attracted significantly more Stomoxys, species overlooked, than the unbaited control trap: Acacia albida, A. macrostachya, Ziziphus mauritiana, Guiera senegalensis, Boscia angustifolia, Leptadenia pyrotechnica, A. nilotica, A. sieberiana and Cassia siamea. The overlapping significance levels have been omitted here because they are more meaningful when the fly species are examined individually. There were no significant differences in attraction between the flowers of the remaining 17 plants and the unbaited control trap.

The flowers of A. albida were the most attractive to S. calcitrans and S. niger bilineatus, but the flowers of Acacia macrostachya were most attractive to $S$. sitiens. These flowers attracted significantly more individuals than did their respective control traps (Table 4). However, the significance levels were wide and overlapping for all three Stomoxys species and little can be said about significant differences in attraction. The species captured in the largest numbers was S. sitiens, but the highest relative attraction ratios were those of $S$. niger bilineatus. Of the 26 flowers tested, 9 were the most attractive to all three Stomoxys species, although not entirely in the same order (Table 4). The unbaited control traps captured numerically more individuals of all three Stomoxys species than some of the flower-baited traps. Flowers from 13 plant species, e.g. Hybiscus sabdarifa, Cassia occidentalis, Hypomoea asarifolia and Hyptis suaveolens (Table 2), attracted numerically fewer $S$ sitiens than the unbaited control. There were no significant differences between blocks or days. The relative attraction to flowers by $S$. niger bilineatus was much higher than it was for the other two Stomoxys species (Table 4).

\section{Stomoxys sugar feeding}

The percentages of sugar-fed Stomoxys of all three species found at the lagoon site were significantly greater than those at the Mopti site (Fig. 1); however, there were no significant differences between the percentages of sugar-fed Stomoxys species at either site.

The species with the highest percentage of sugar-fed individuals at both sites was S. sitiens $(33.8 \pm 4.2 \%$ at Mopti and $72.1 \pm 4.1 \%$ at the lagoon). The percentage of sugar-fed S. niger bilineatus at Mopti was greater than that of S. calcitrans ( $25.8 \pm 3.9$ and $15.3 \pm 2.3 \%$, respectively), but the reverse was found at the lagoon $(51.6 \pm 5.3$ and $57.3 \pm 4.9 \%$, respectively).

\section{Diurnal feeding activity}

When analysed by bait type, both models were significant (A. albida: $F=10.85$, d.f. $=26,255, P<0.0001$; donkey: $F=5.29$, d.f. $=35,317, P<0.0001)$ for time and fly species, but not for rep. The mean number of $S$. calcitrans (7.4 \pm 0.09$)$ attracted to A. albida was significantly higher than those of $S$. niger bilineatus $(6.0 \pm 0.09)$ and S. sitiens $(4.2 \pm 0.07)$, which were significantly different from each other. The mean number of $S$. niger bilineatus $(8.8 \pm 0.10)$ attracted to the donkey was significantly higher than those of $S$. caltrans $(5.7 \pm 0.07)$ and $S$. sitiens $(5.0 \pm 0.08)$, which were not significantly different from each other.

All three Stomoxys species have a blood-feeding activity period in the morning and again in the evening and one sugar-feeding activity period during midday (Fig. 1). The onset of blood-feeding activity for S. niger bilieatus was the earliest of the three species, beginning $30 \mathrm{~min}$ before sunrise at 06.30 hours, with an acrophase between 08.00 and 08.30 hours. This was followed by a complete cessation of blood-feeding activity between 11.00 and 11.30 hours. Sugar feeding activity began between 09.30 and 10.00 hours with well-defined peaks between 11.30 and 12.00 hours, and between 14.00 and 14.30 hours. This was followed by complete cessation between 16.00 and 16.30 hours. Bloodfeeding activity began again between 15.30 and 16.00 hours, peaked between 18.30 and 19.00 hours, and then ended between 20.30 and 21.00 hours, about $2 \mathrm{~h}$ after sunset (Fig. 1). There was no significant difference between the morning blood-feeding activity peak $(16.5 \pm 4.40)$ and the midday sugar-feeding activity peak $(19.5 \pm 3.60)$, but the afternoon blood-feeding activity peak $(39.0 \pm 9.60)$ was significant and about twice as high as the morning or midday activity peaks (Fig. 1).

Stomoxys sitiens-feeding activity was similar to $S$. niger bilineatus, with some overlap between blood-feeding and 

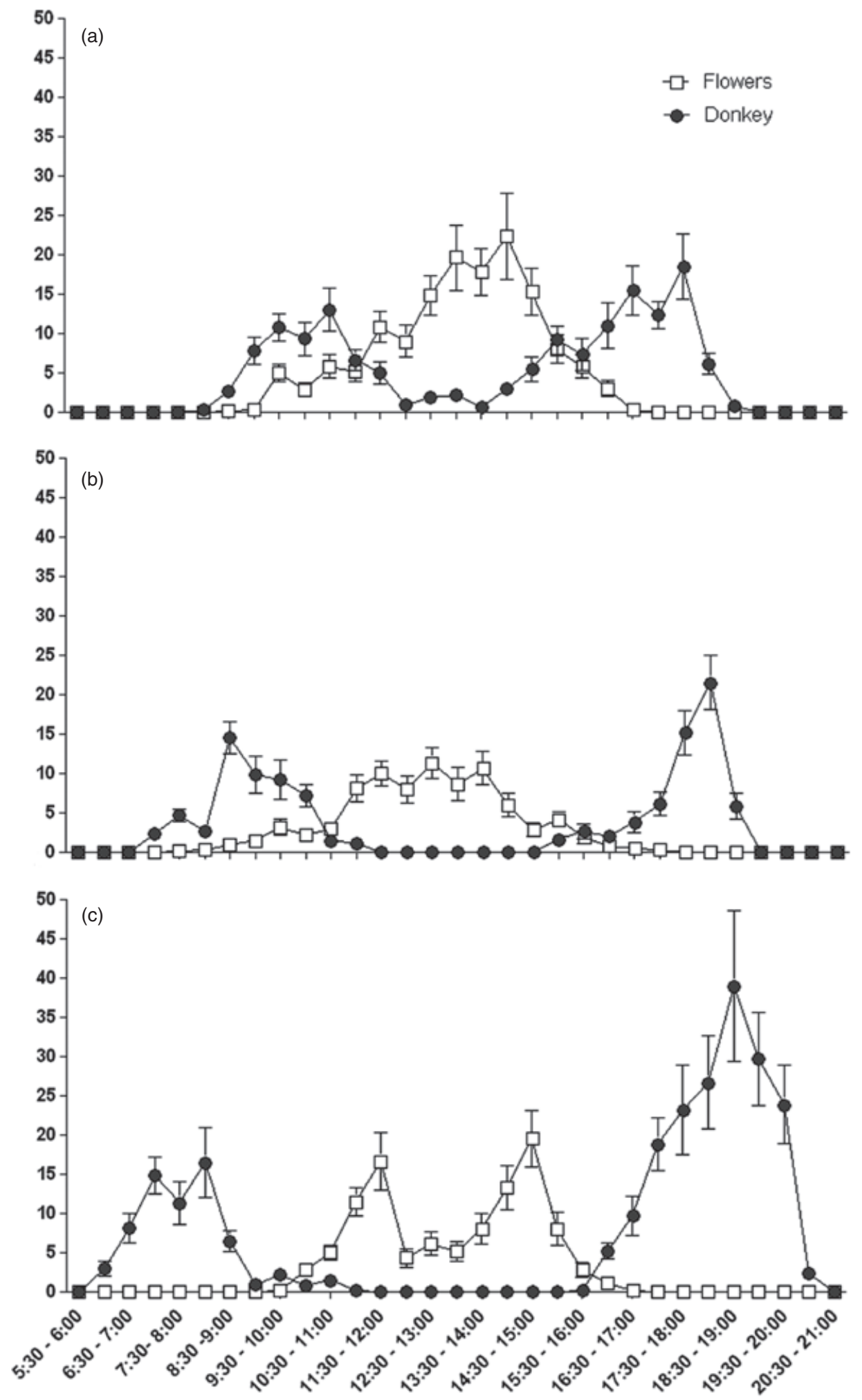

Fig. 1. Diurnal feeding behaviour of the three Stomoxys species. Average number ( \pm S.E.) of flies caught on blood source or on Acacia albidabaited trap hourly throughout the day. Six repetitions for each time period were obtained with two donkeys and two groups of flower-baited traps for three consecutive days. (A) S. calcitrans. (B) S. sitiens. (C) S. niger bilineatus. The two arrows indicate the time of sun rise and sun set. $\square$ blood-feeding activity, $\bullet$ sugar-feeding activity. 
sugar-feeding activity periods, but by small numbers of flies. The first blood-feeding activity period began at sunrise (06.30 hours), peaked between 08.30 and 09.00 hours, and ended between 11.30 and 12.00 hours. Sugar-feeding activity began between 07.30 and 08.00 hours, peaked between 12.30 and 14.00 hours, and was followed by complete cessation between 17.00 and 17.30 hours (Fig. 1). The second bloodfeeding activity period started between 15.00 and 15.30 hours, peaked between 18.00 and 18.30 hours, and then subsided between 19.00 and 19.30 hours, about $1 \mathrm{~h}$ after sunset (Fig. 1). There were no significant differences between the morning blood-feeding activity peaks $(14.5 \pm 2.08)$, the midday sugarfeeding activity peak $(11.3 \pm 1.91)$ and the afternoon bloodfeeding activity peak $(21.5 \pm 3.45)$ (Fig. 1).

There was no separation between the sugar-feeding and blood-feeding activity periods for S. calcitrans (Fig. 1). One continuous day-long blood-feeding activity period began between 08.00 and 08.30 hours, about $2 \mathrm{~h}$ after sunrise, and ended between 18.30 and 19.00 hours. Blood-feeding activity peaked between 10.30 and 11.00 hours, decreased to its low point between 13.30 and 14.00 hours, and then peaked again between 17.30 and 18.00 hours. Sugar-feeding activity occurred throughout most of the blood-feeding activity period starting between 08.30 and 09.00 hours, peaking between 14.00 and 14.30 hours, and ending between 16.30 and 17.00 hours (Fig. 1). Stomoxys calcitrans was the only species for which the sugar-feeding activity peak $(22.3 \pm 5.4)$ was numerically higher than the morning and afternoon blood-feeding activity peaks (13.0 \pm 2.6 and $18.4 \pm 4.2$, respectively). The daily activity period for $S$. calcitrans was also found to be 1 and $3.5 \mathrm{~h}$ shorter than those of $S$. sitiens and $S$. niger bilinenatus, repectively.

\section{Discussion}

The present study has clearly shown that certain Stomoxys species regularly feed on sugars with high prevalence. Other blood-feeding flies, e.g. mosquitoes (Bowen, 1992), phlebotomine sand flies (Schlein \& Warburg, 1986), culicoides
(Stewart \& Kline, 1999) and tabanids (Foil \& Hogsette, 1994), are known to have a similar affinity for carbohydrate sources, and feed more often on sugars than blood (Foster, 1995). Early observations of stable flies visiting flowers, apparently to imbibe nectar, were made, not in Africa, but in Europe (Surcouf, 1921). It has since been shown that stable flies not only visit flowers but actually do feed on nectar (Tseng et al., 1983; Jones et al., 1985). However, regular, long-term feeding on sugar sources has only been shown with S. calcitrans in NE, U.S.A. (Taylor \& Berkebile, 2008) and with the three Stomoxys species we collected in Mali.

When Goodwin et al. (1986) conducted studies in Mali, they collected five species in two genera of Stomoxyinae: Stomoxys calcitrans, S. niger bilineatus, S. sitiens, Haematobia minuta Bezzi and H. thirouxi Roubard. The fact that we collected the same three Stomoxys species indicates that they are well established in the region. If other Stomoxys species were present, they were not attracted to the fruits and flowers we evaluated. In the present study, S. sitiens was most numerous around flowers and $S$.niger bilineatus was most numerous around fruits. It has been reported that S. calcitrans can be quite numerous in areas where cattle are being kept by humans, but less numerous in more natural conditions (Ndegwa \& Ogodo, 2002). This situation did not exist in Mali.

All three Stomoxys species showed some degree of attraction to the unbaited glue traps used to cover the fruits and flowers. The addition of a sponge saturated with a sugar solution did not increase this attraction and the addition of some fruits and flowers actually reduced this attraction. The glue traps by themselves probably provided the structure that these flies prefer for resting sites in open areas. This has been observed in agricultural situations where numbers of stable fly adults in open pastures are low unless there are structures, such as feed troughs or mineral boxes, on which the flies can rest (Hogsette et al., 1987). These plastic traps served as passive sticky covers over the various fruits and flowers, and did not demonstrate any degree of attraction that would classify them for use as stand-alone visual traps, such as alsynite (Hogsette \& Ruff, 1990) or coroplast (Beresford \& Sutcliffe, 2006).

Table 3. Mean numbers ( \pm S.E.) and relative attraction ratios of Stomoxys species captured at the eight most attractive fruits of selected plant species in Mali $(n=6)$.

\begin{tabular}{|c|c|c|c|c|c|c|}
\hline \multirow[b]{2}{*}{ Plant species } & \multicolumn{3}{|c|}{ Stomoxys spp. captured } & \multicolumn{3}{|c|}{ Relative attraction ratios } \\
\hline & S. calcitrans & S. niger bilineatus & S. sitiens & S. calcitrans & S. niger bilineatus & S. sitiens \\
\hline Piliostigma reticulatum & $8.1 \pm 1.5 \mathrm{a}$ & $19.5 \pm 1.2 \mathrm{a}$ & $4.7 \pm 1.2 \mathrm{a}$ & 6.1 & 7.0 & 10.9 \\
\hline Tamarindus indica & $4.8 \pm 1.1 \mathrm{ab}$ & $10.3 \pm 1.2 \mathrm{abcd}$ & $3.1 \pm 1.1 \mathrm{abcde}$ & 3.7 & 3.7 & 7.1 \\
\hline Psidium guajava & $4.0 \pm 1.2 \mathrm{abc}$ & $14.9 \pm 1.2 \mathrm{ab}$ & $4.2 \pm 1.2 \mathrm{ab}$ & 3.0 & 5.3 & 9.8 \\
\hline Cucumis melo & $3.5 \pm 1.3 \mathrm{abc}$ & $7.8 \pm 1.2 \mathrm{abcde}$ & $2.9 \pm 1.2 \mathrm{abcde}$ & 2.6 & 2.8 & 6.7 \\
\hline Saccharum officinarum & $3.3 \pm 1.2 \mathrm{abc}$ & $6.8 \pm 1.3 \mathrm{bcdef}$ & $3.8 \pm 1.2 \mathrm{abc}$ & 2.5 & 2.4 & 8.8 \\
\hline Carica papaya & $2.6 \pm 1.2 \mathrm{abc}$ & $5.5 \pm 1.2 \mathrm{bcdefg}$ & $2.4 \pm 1.1 \mathrm{abcdef}$ & 2.0 & 2.0 & 5.6 \\
\hline Ficus thonningii & $2.6 \pm 1.3 \mathrm{abc}$ & $10.6 \pm 1.1 \mathrm{abc}$ & $3.4 \pm 1.1 \mathrm{abcd}$ & 1.9 & 3.8 & 7.8 \\
\hline Phoenix dactylifera & $2.3 \pm 1.2 \mathrm{bc}$ & - & $2.4 \pm 1.3 \mathrm{abcdef}$ & 1.8 & - & 5.5 \\
\hline Balanitis eagyptiacus & - & $5.6 \pm 1.2 \mathrm{bcdefg}$ & - & - & 2.0 & - \\
\hline Control & $1.3 \pm 1.3 b c$ & $2.8 \pm 1.3 \mathrm{efg}$ & $0.4 \pm 1.2 \mathrm{f}$ & - & - & - \\
\hline
\end{tabular}

Means in columns followed by the same letter are not significantly different $[P<0.05$; Ryan-Einot-Gabriel-Welsch Multiple Range Test (SAS Institute, 2003)]. 
Table 4. Mean numbers ( \pm S.E.) and relative attraction ratios of Stomoxys species captured at the nine most attractive flowers of selected plant species in Mali $(n=6)$.

\begin{tabular}{|c|c|c|c|c|c|c|}
\hline \multirow[b]{2}{*}{ Plant species } & \multicolumn{3}{|c|}{ Stomoxys spp. captured } & \multicolumn{3}{|c|}{ Relative attraction ratios } \\
\hline & S. calcitrans & S. niger bilineatus & S. sitiens & S. calcitrans & S. niger bilineatus & S. sitiens \\
\hline Acacia albida & $11.5 \pm 1.2 \mathrm{a}$ & $15.3 \pm 1.2 \mathrm{a}$ & $22.2 \pm 1.2 \mathrm{a}$ & 12.7 & 21.9 & 8.5 \\
\hline Ziziphus mauritiana & $8.7 \pm 1.2 \mathrm{ab}$ & $9.7 \pm 1.2 \mathrm{ab}$ & $18.9 \pm 1.2 \mathrm{ab}$ & 9.7 & 13.9 & 7.3 \\
\hline Acacia macrostachya & $7.0 \pm 1.2 \mathrm{abc}$ & $13.3 \pm 1.1 \mathrm{ab}$ & $27.3 \pm 1.2 \mathrm{ab}$ & 7.8 & 19.0 & 10.5 \\
\hline Leptadenia pyrotechnica & $5.2 \pm 1.2 \mathrm{abcd}$ & $7.2 \pm 1.2 \mathrm{abc}$ & $13.8 \pm 1.2 \mathrm{abcd}$ & 5.8 & 10.3 & 5.3 \\
\hline Boscia angustifolia & $4.9 \pm 1.2 \mathrm{abcde}$ & $6.8 \pm 1.2 \mathrm{abc}$ & $16.7 \pm 1.2 \mathrm{abc}$ & 5.4 & 9.7 & 6.4 \\
\hline Guiera senegalensis & $3.4 \pm 1.2 \mathrm{abcdef}$ & $8.2 \pm 1.1 \mathrm{abc}$ & $17.7 \pm 1.2 \mathrm{abc}$ & 3.8 & 11.7 & 6.8 \\
\hline Acacia nilotica & $4.1 \pm 1.2 \mathrm{abcdef}$ & $5.2 \pm 1.1 \mathrm{bcd}$ & $10.4 \pm 1.1 \mathrm{abcde}$ & 4.6 & 7.4 & 4.0 \\
\hline Acacia sieberiana seed pod & $3.5 \pm 1.3 \mathrm{abcdef}$ & $6.1 \pm 1.2 \mathrm{abc}$ & $7.8 \pm 1.2 \mathrm{abcdef}$ & 3.9 & 8.7 & 3.0 \\
\hline Cassia siamea & $2.5 \pm 1.3 \mathrm{bcdefg}$ & $2.9 \pm 1.2 \mathrm{cde}$ & $9.8 \pm 1.2 \mathrm{abcdef}$ & 2.8 & 3.1 & 3.8 \\
\hline Control & $0.9 \pm 1.3 \mathrm{defg}$ & $0.7 \pm 1.3 \mathrm{ef}$ & $2.6 \pm 1.2 \mathrm{fghi}$ & - & - & - \\
\hline
\end{tabular}

Means in columns followed by the same letter are not significantly different $[P<0.05$; Ryan-Einot-Gabriel-Welsch Multiple Range Test (SAS Institute, 2003)].

At least some of the Stomoxys sp. demonstrated clear preferences to fruit and flowers if given the choice, indicating specific rather than opportunistic sugar-feeding habits. From the selected variety of cultivated and wild fruit that we evaluated, interestingly the seed pods of $P$. reticulatum were the most attractive to all three Stomoxys sp. (Table 3). Seed pods of tamarinds, $T$. indica, also attracted significant numbers of $S$. niger bilineatus and S. sitiens. The seed pods of both plant species are locally known and used for their high sugar content. Two of the five fruits which attracted significant numbers of $S$. sitiens were the cultivated species of guava, P. guajava, and honey melon, C. melo. Guava and $F$. thonningii were also the only fruits to significantly attract $S$. niger bilineatus. The fact that the cosmopolitan $S$. calcitrans was attracted significantly to only one local fruit suggests that specificity to local flora is not an indicator of species distribution capability.

The attraction of all three Stomoxys species to flowers was more pronounced than their attraction to fruits. This might be a result of the volatiles released by the flowers, the nectar they provide and the potential for increased viability between bloodmeals (Taylor \& Berkebile, 2008). In our experiments, the shape and colour of both fruits and flowers were partially masked by the glue traps. Thus in these evaluations, the flies were attracted mainly by the chemical components of these baits. Also, it is not certain if or how much an optical component of attraction has contributed to the results of these experiments.

The fact that the flies were not attracted to all of the flowers could be due in part to a lack of an optical component or flower designs which prevent extraction of nectar by Stomoxys. It is worthwhile mentioning that the fruits as well as all of the attractive flowers offer an easy landing platform and the nectar can be easily reached by the flies; however, this is not the case with many of the non-attractive flowers. All of the attractive flowering plants are trees and bushes and most of these bloom continuously, even during the dry season. None of the annuals we evaluated, all of which bloom during the rainy season or shortly thereafter, were attractive to the flies.
Cold anthrone assays of flies caught at both Mopti and the lagoon sites indicate that a greater percentage of sugarfed flies can be found where suitable nectar sources are readily available. This is supported by the work of Jones et al. (1985) who found a higher percentage of sugar-fed S. calcitrans at natural beach sites than at dairies in FL, U.S.A. The lagoon site, a natural habitat with numerous flowering and fruited trees, offers many opportunities for sugar. There was nothing comparable between the rice fields at Mopti. Because the availability of blood sources at the two sites was similar, the number of sugar-fed flies caught at the lagoon site indicates that sugar-feeding is a highly important aspect of Stomoxys behaviour.

Sugar feeding has been shown to cause decreases in viability and reproduction rates in $S$. calcitrans whereas blood-feeding does much the opposite (Jones et al., 1992). Perhaps the concomitant feeding on sugar and blood acts as a populationregulating mechanism and the effects are determined by the proportions of blood and sugar that are consumed. Hogsette et al. (1987) suggested that sugar meals are used to sustain Stomoxys populations when bloodmeal availability is low. This probably occurs during certain periods of the year, as the numbers of host animals and nectar sources are subject to seasonal variation. A 12-month study would provide additional knowledge about the relationship of blood and nectar feeding.

When the rhythm of Stomoxys feeding activity was evaluated using donkeys and flowers, the fact that sugar feeding is as important in Stomoxys ecology as blood-feeding was emphasized once again. All three species were found to have sugarfeeding peaks as high as the morning blood-feeding peaks, but the afternoon blood-feeding period of S. niger bilineatus was statistically higher than the sugar-feeding peak. Surprisingly, $S$. calcitrans, which was less responsive in the fruit and flower comparisons, was found to have a numerically higher, but not significantly different, sugar-feeding acrophase than both blood-feeding peaks.

Comparison between the species revealed an interesting temporal separation between $S$. calcitrans and S. niger bilineatus for the morning blood-feeding activity, but not during the midday sugar-feeding period. Stomoxys niger bilineatus was also 
shown to have a longer daily activity period, possibly to avoid competition with the other Stomoxys species or with predators.

Bimodal blood-feeding activity periods for various Stomoxys species can be found in the literature, however, sugar-feeding activity periods have until now been overlooked. Kunz \& Monty (1976) and Mihok et al. (1996) both reported hourly blood-feeding curves for S. calcitrans that are bimodal but of longer duration than we found in Mali. This indicates that these activity periods are dependent upon local conditions.

During the present study, it was observed daily that cattle egrets were picking large numbers of blood-feeding flies during the whole day from cattle. In addition, from the late afternoon until sunset, many thousands of dragon flies (Brachythemis leucosticta Burmeister, Libellulidae) were specifically hunting for flies hovering around and feeding on cattle.

The present study provides preliminary data on the attraction of Stomoxys species to plant species, demonstrating that they are regular sugar feeders, even when constant blood sources are available. All three Stomoxys species were shown to be attracted more to flowers than to fruit. Further studies are needed to better understand the underlying factors at the base of sugar-seeking behaviour. Elucidation of the volatile compounds present in the plants attractive to Stomoxys could help to create more efficient traps for both scientific studies and for controlling Stomoxys infestations. The fact that three different Stomoxys species are attracted to the same plant species, and only to a selected few out of the 54 which were tested, is an encouraging result. Possibly Stomoxys control methods might consist of treatment/removal of a few attractive plant species in the areas surrounding rural communities. Fruits could be used to produce bait solutions that could be spiked with oral toxins for application near breeding and resting sites. Similar experiments with several mosquito species and sand flies have been very encouraging.

\section{References}

Beresford, D.V. \& Sutcliffe, J.F. (2006) Studies on the effectiveness of Coroplast sticky traps for sampling stable flies (Diptera: Muscidae), including a comparison to Alsynite. Journal of Economic Entomology, 99, 1025-1035.

Bowen, M.F. (1992) Terpene-sensitive receptors in female Culex pipiens mosquitoes: electrophysiology and behavior. Journal of Insect Physiology, 38, 759-764.

Bruce, W.N. \& Decker, G.C. (1958) The relationship of stable fly abundance to milk production in dairy cattle. Journal of Economic Entomology, 51, 269-274.

Campbell, J.B., Berry, I.L., Boxler, D.J., Davis, R.L., Clanton, D.C. \& Deutscher, G.H. (1987) Effects of stable flies (Diptera: Muscidae) on weight gain and feed efficiency of feedlot cattle. Journal of Economic Entomology, 80, 117-119.

Campbell, J.B., Skoda, S.R., Berkebile, D.R., Boxler, D.J., Thomas, G.D., Adams, D.C. \& Davis, R. (2001) Effects of stable flies (Diptera : Muscidae) on weight gains of grazing yearling cattle. Journal of Economic Entomology, 94, 780-783.

D’Amico, F., Gouteux, J.P., Le Gall, F. \& Cuisance, D. (1996) Are stable flies (Diptera: Stomoxyinae) vectors of Trypanosoma vivax in the Central African Republic? Veterinary Research, 27, 161-170.
Eavy, L., Ankli, K., Brandell, C. et al. (1981) Biology, economics, and management of the stable fly as a recreational pest. Final Technical Report, SPI-79-03441, p. 103. The University of Michigan Stable Fly Study Project, Ann Arbor, MI.

Foil, L.D. \& Hogsette, J.A. (1994) Biology and control of tabanids, stable flies and horn flies. Revue Scientifique et Technique (Office International des Epizooties Paris), 13, 1125-1158.

Foster, W.A. (1995) Mosquito sugar feeding and reproductive energetics. Annual Review of Entomology, 40, 443-474.

Goodwin, J.T., Boomer, W.P., Logan, L.L. \& Olsen, J.K. (1986) Maintaining zebu maure cattle in a tsetse infested area of Mali. II. Epidemiological considerations. Tropical Animal Health and Production, 18, 1-12.

Hogsette, J.A. \& Farkas, R. (2000) Secretophagous and hematophagous higher Diptera. Contributions to a Manual of Palearctic Diptera, Vol. 1 General and Applied Dipterology (ed. by L. Papp \& B. Darvas), pp. 769-792. Science Herald, Budapest.

Hogsette, J.A. \& Ruff, J.P. (1990) Comparative attraction of four different fiberglass traps to various age and sex classes of stable fly (Diptera: Muscidae) adults. Journal of Economic Entomology, 83, 883-886.

Hogsette, J.A., Ruff, J.P. \& Jones, C.J. (1987) Stable fly biology and control in Northwest Florida. Journal of Agricultural Entomology, 4, 1-11.

Hogsette, J.A., Nalli, A. \& Foil, L.D. (2008) Evaluation of different insecticides and fabric types for development of treated targets for stable fly (Diptera: Muscidae) control. Journal of Economic Entomology, 101, 1034-1038.

Jarzen, D.M. \& Hogsette, J.A. (2008) Pollen from the exoskeletons of stable flies, Stomoxys calcitrans (Linnaeus 1758), in Gainesville, Florida, U.S.A. Palynology, 32, 77-81.

Jones, C.J., Hogsette, J.A., Patterson, R.S. \& Milne, D.E. (1985) Effects of natural saccharide and pollen extract feeding on stable fly (Diptera: Muscidae) longevity. Environmental Entomology, 14, 223-227.

Jones, C.J., Milne, D.E., Patterson, R.S., Schreiber, E.T. \& Milio, J.A. (1992) Nectar feeding by Stomoxys calcitrans (Diptera: Muscidae): effects on reproduction and survival. Environmental Entomology, 21, 141-147.

Kunz, S.E. \& Monty, J. (1976) Biology and ecology of Stomoxys nigra Macquart and Stomoxys calcitrans (L.) (Diptera: Muscidae) in Mauritius. Bulletin of Entomological Research, 66, 745-755.

Mellor, P.S., Kitching, R.P. \& Wilkinson, P.J. (1987) Mechanical transmission of capripoxvirus and African swine fever virus by Stomoxys calcitrans. Research in Veterinary Science, 43, 109-112.

Mihok, S. \& Clausen, P.H. (1996) Feeding habits of Stomoxys spp. stable flies in a Kenyan forest. Medical and Veterinary Entomology, 10, 392-394.

Mihok, S., Kang'ethe, E.K. \& Kamau, G.K. (1995a) Trials of traps and attractants for Stomoxys spp. (Diptera: Muscidae). Journal of Medical Entomology, 32, 283-289.

Mihok, S., Maramba, O., Munyoki, E. \& Kagoiya, J. (1995b) Mechanical transmission of Trypanosoma spp. by African Stomoxyinae (Diptera: Muscidae). Tropical Medicine and Parasitology, 46, $103-105$.

Mihok, S., Maramba, O., Munyoki, E. \& Saleh, K. (1996) Phenology of Stomoxyinae in a Kenyan forest. Medical and Veterinary Entomology, 10, 305-316. 
Moobola, S.M. \& Cupp, E.W. (1978) Ovarian development in the stable fly, Stomoxys calcitrans, in relation to diet and juvenile hormone control. Physiological Entomology, 3, 317-321.

Ndegwa, P.N. \& Ogodo, J.A. (2002) Community structure and diel activity patterns of Stomoxyinae from odour-baited Nzi trap collections. Insect Science and its Application, 22, 281-287.

Potgieter, F.T., Sutherland, B. \& Biggs, H.C. (1981) Attempts to transmit Anaplasma marginale with Hippobosca rufipes and Stomoxys calcitrans. Onderstepoort Journal of Veterinary Research, 48, 119-122.

SAS Institute (2003) SAS/STAT User's Guide Version 9.1. SAS Institute, Cary, NC.

Schlein, Y. \& Warburg, A. (1986) Phytophagy and the feeding cycle of Phlebotomus papatasi (Diptera: Psychodidae) under experimental conditions. Journal of Medical Entomology, 23, 11-15.

Scoles, G.A., Broce, A.B., Lysyk, T.J. \& Palmer, G.H. (2005) Relative efficiency of biological transmission of Anaplasma marginale (Rickettsiales: Anaplasmataceae) by Demacentor andersoni (Acari: Ixodidae) compared with mechanical transmission by Stomoxys calcitrans (Diptera: Muscidae). Journal of Medical Entomology, 42, 668-675.

Stewart, R.G. \& Kline, D.L. (1999) Sugar feeding by Culicoides mississippiensis (Diptera: Ceratopogonidae) on Yaupon Holly, Ilex vomitoria. Journal of Medical Entomology, 36, 268-271.
Sumba, A.L., Mihok, S. \& Oyieke, F.A. (1998) Mechanical transmission of Trypanosoma evansi and T. congolense by Stomoxys niger and $S$. taeniatus in a laboratory mouse model. Medical and Veterinary Entomology, 4, 417-422.

Surcouf, J.M.R. (1921) Notes biologiques sur certains Dipteres. Bulletin de la Musee d'Histoire Naturelle de Paris, 27, 67-74.

Taylor, D.B. \& Berkebile, D. (2006) Comparative efficiency of six stable fly (Diptera: Muscidae) traps. Journal of Economic Entomology, 99, 1415-1419.

Taylor, D.B. \& Berkebile, D. (2008) Sugar feeding in adult stable flies. Environmental Entomology, 37, 625-629.

Tseng, J.M., Jones, C.J. \& Hogsette, J.A. (1983) Nectar feeding and the stable fly, Stomoxys calcitrans (Diptera: Muscidae). Florida Anti-Mosquito Association, 54, 40-41.

Van Handel, E. (1967) Determination of fructose and fructose-yielding carbohydrates with cold anthrone. Analytical Biochemistry, 19, 193-194.

Zumpt, F. (1973) The Stomoxyine Biting Flies of the World. Gustav Fischer Verlag, Stuttgart.

Accepted 20 July 2011

First published online 13 February 2012 